\title{
PENETRASI KAPITALIS DAN RESISTENSI PETANI: KASUS SENGKETA AGRARIA DI TANAH LIDO KABUPATEN BOGOR, JAWA BARAT
}

\author{
Septri Widiono \\ Jurusan Sosial Ekonomi Pertanian Fakultas Pertanian Universitas Bengkulu
}

\begin{abstract}
This research was aimed to study about an agrarian conflict at Lido land. In order to get the comprehensive its meaning the qualitative approach with the case study strategy were used. The conflict explained as the dialectical relation among peasants in the one hand and the agrotourism company in the other hand. The conflict taken place with the support of local government to the company while peasants made patronize relationship with the NGO. The dynamic of agrarian conflict has meaning of capitalist penetration and the peasant resistency.
\end{abstract}

Keyword: agrarian conflict, capitalist penetration, peasant resistency, Lido

\section{PENDAHULUAN}

Era reformasi diakui membawa perubahan pada beberapa bidang kehidupan. Perubahan itu tampak pada fenomena seperti: demokratisasi politik, desentralisasi daerah, revisi undangundang dan peraturan lainnya, menguatnya civil society, pengakuan hak-hak azasi manusia, dan lain-lain. Di bidang hokum lahir peraturan penataan agraria, yaitu TAP MPR No. IX tahun 2001 tentang pembaruan agraria dan sumberdaya alam.

Penetapan TAP MPR No. IX tahun 2001 yang semestinya dijalankan oleh presiden masih jauh dari harapan. Belum adanya political will pemerintah untuk menata penguasaan agraria secara adil menjadi satu problema besar bangsa Indonesia, khususnya petani. Disadari pula bahwa reformasi sekarang ini berada di persimpangan jalan antara masa orde baru yang otoriter dan masa depan yang lebih berkeadilan. Dampak berkuasanya orde baru terasa sebagai realitas sosial tersendiri yang perlu mendapat perhatian serius. Ketidakberdayaan petani akibat proses sistematis masa lalu yang menempatkan petani sebagai objek penderita pembangunan berwatak kapitalis masih kentara.

Oleh sebab itu dalam formasi sosial kapitalis semacam ini, pernyataan Clifford Geertz (1991) masih relevan untuk membangun argumentasi teoretis dalam penelitian ini. Dikatakan bahwa perubahan sosial yang terjadi pada masyarakat petani cukup beragam. Perubahan yuridis berkenaan dengan undang-undang pemilikan tanah; perubahan teknologis berkaitan dengan metode pertanian; perubahan ekonomi berhubungan dengan penanaman modal, pemasaran dan ketenagakerjaan; perubahan politik menyangkut hubungan kekuasaan; perubahan sosiologis 
berhubungan dengan struktur masyarakat; dan perubahan kultural berkenaan dengan pemahaman diri. Semua perubahan itu bermuara pada satu inti persoalan yang sama yang tidak pernah diseimbangkan dan diselesaikan, yaitu penggunaan tanah (Geertz dalam Pelzer 1991).

Sengketa tanah banyak yang belum tertunaikan. Salah satu penyebab merebaknya konflik agraria pada masa orde baru -yang masih dirasakan saat ini- secara pokok ditimbulkan oleh kebijakan pemerintah yang lebih melindungi pemodal swasta daripada rakyat kecil (petani). Dasar utamanya swasta berusaha menggunakan faktor produksi tanah secara efisien untuk mencapai tujuan tertentu. Cara kerja inilah yang menjadi dasar pemicu bagi petani untuk melakukan tindak perlawanan. Dalam skala yang luas, sengketa antara petani dan swasta masih terus berlanjut dalam ekskalasi tertentu, misalnya kasus Kedung Ombo (Stanley 1994), Jenggawah (Hafid 2001), Cimacan, dan Tapos (Bachriadi dan Lucas 2001).

Dalam skala lokal, sengketa tanah banyak juga terjadi di Bogor. Beberapa kasus yang terekam media massa antara lain sengketa tanah di Kampung Cikarang Desa Pabuaran Kecamatan Gunung Sindur. Petani menggarap 19 hektar tanah bekas HGU PTPN VIII yang berakhir tahun 2001, ternyata sudah dikuasakan kepada PT Royal Astrindo (Radar Bogor 10 November 2000). Kemudian sengketa di Desa Malasari, Kecamatan Nanggung. Dalam kasus ini petani menuntut agar HGU PT Nirmala Agung tidak diperpanjang dan diserahkan kepada petani (Radar Bogor 30 Oktober 2000). Pembuldoseran 145 hektar tanah garapan petani oleh PT Bukit Sentul yang mengantongi HGB. Dalam kasus ini petani meminta ganti rugi tanah sesuai harga pasar yakni sebesar Rp 2000-Rp 4000 per meter persegi (Radar Bogor 16, 18, 19, 28 Oktober 2000; 13 November 2000; 26 April 2001). Juga sengketa di kawasan Puncak yang terjadi di Kampung Citamiang Desa Tugu Utara, Cisarua. Pembangunan villa milik orang Jakarta di atas lahan garapan petani membuahkan konflik dengan petani (Radar Bogor 23 April 2001).

Kasus petani penggarap Lido di Kecamatan Cijeruk adalah salah satu dari banyaknya sengketa tanah di Bogor lainnya sebagaimana disebut di atas. Sengketa terjadi melibatkan petani dengan sebuah perusahaan pengembang agrowisata (AP). Untuk keperluan mengeksplorasi kasus ini, pembahasan akan difokuskan pada perlawanan petani yang tergabung ke dalam Paguyuban Petani Penggarap Lido (P3L). Munculnya perlawanan petani secara teoretis dapat didekati dengan teori ekonomi moral Scott $(1983,1993,2000)$. Teori ekonomi moral menjelaskan kegiatan pertanian petani dan juga beragam kegiatan di luar pertanian merupakan budaya untuk memenuhi kebutuhan subsisten. Kehidupan petani dibimbing oleh etika subsistensi dan lebih mengutamakan selamat (safety first). Pada ambang batas subsistensi ini petani dapat menjalani 
kehidupan normal. Apabila ambang ini terlampaui, terjadilah krisis subsistensi yang mendorong terjadinya resistensi baik dalam bentuk sembuyi-sembuyi (weapon of the weak) maupun terangterangan (rebellion). Scott mendefinisikan perlawanan kaun tani sebagai:

"Setiap aksi yang dilakukan oleh seorang atau lebih petani yang dimaksud untuk mengurangi atau menolak berbagai tuntutan (misalnya: sewa, pajak, kerja paksa, kepatuhan) dari kelas-kelas orang berada (missal: tuan tanah, Negara, rentenir) atau untuk mengajukan tuntutan kaum tani (missal: atas tanah, sumbangan, penghargaan) terhadap kelas-kelas orang berada ini" (Scott 1993)

Pendekatan teori ekonomi moral akan dipergunakan untuk membingkai argumentasi kasus sengketa agraria di Lido sebagai suatu proses aksi-reaksi antara pemilik modal swasta dengan golongan petani di desa. Proses aksi-reaksi itu mewujud dalam hubungan penetrasi dari pihak swasta dan resistensi dari pihak petani. Penetrasi dilihat dari upaya-upaya pihak swasta dalam rangka mewujudkan skala produksi industri agrowisata yang berimplikasi pada kehidupan petani. Sebaliknya resistensi dilihat dari upaya-upaya petani untuk menjaga kelangsungan pemenuhan kebutuhan subsistensi yang juga mempunyai dampak terhadap swasta.

\section{METODOLOGI}

Penelitian ini merupakan jenis penelitian kualitatif di bawah paradigma teori kritis (Denzin dan Lincoln 2000). Data-data primer yang digunakan meliputi kata-kata dan tindakan, serta dokumen sebagai data tambahan (Lofland dan Lofland dikutip oleh Moleong 2001) yang merupakan hasil pengamatan, pembicaraan, dan bahan tertulis (Patton dikutip oleh Sitorus 1998). Sebagai konsekuensi pradigma kritis ini, ceritanya "orang-orang yang kalah" (Scott 2000) menjadi sumber data utama dengan tujuan untuk mendapatkan pemahaman kritis terhadap proses sosial yang tengah terjadi. Untuk mencapai pemahaman di atas digunakan strategi studi kasus dengan informan kunci sebanyak 9 orang dan responden kasus sebanyak 2 orang. Studi kasus dilaksanakan di Desa Wates Jaya Kecamatan Cijeruk Kabupaten Bogor. Secara prinsip, proses analisis data dilakukan secara simultan dan siklikal dengan memposisikan diri pada empat sumbu, yaitu pengumpulan data, reduksi data, penyajian data, dan penarikan/verifikasi kesimpulan (Miles dan Huberman 1992). Jadi analisis data sudah dimulai pada saat data mulai dikumpulkan, disistematisasi, diperhalus, dan dikonfirmasi ulang kepada informan di lapangan. 


\section{HASIL DAN PEMBAHASAN}

\section{Riwayat Tanah}

Pada zaman kolonial Belanda, daerah Lido beruwujud lahan yang sudah dimanfaatkan oleh masyarakat dan sebagiannya lagi masih berupa hutan tak bertuan. Pemerintah kolonial kemudian mengambil alih tanah milik masyarakat untuk dijadikan perkebunan kopi dan tebu (Perkebunan Pondok Gedeh). Ketika Jepang menduduki Indonesia pada tahun 1942, perkebunan itu dirombak menjadi tanaman singkong, ubi jalar, dan sebagian lagi digunakan untuk memperluas tanaman tebu.

Pasca kejatuhan pemerintahan pendudukan Jepang pada tahun 1945, pengelolaan tanah di kawasan Lido diserahkan kembali kepada masyarakat, yang disebut dengan tanah garapan empat lima. Kemudian pada tahun 1949 ada perencanaan dari pemerintah untuk membuka Perusahaan Perkebunan Negara (PPN) dengan menunjuk Kapten Haris dan Kapten Mulyo sebagai Direksi. Ternyata sampai dengan penunjukan direksi PPN, tanah yang hendak dijadikan sebagai areal perkebunan belum tersedia. Keputusan yang diambil waktu itu adalah menjadikan lahan garapan masyarakat bekas Perkebunan Pondok Gedeh sebagai areal yang dicadangkan untuk PPN. Akan tetapi masyarakat menolak permintaan tersebut, apalagi permintaan itu tidak disertai dengan ganti rugi dari pemerintah. Untuk mengatasi permasalahan tersebut, maka dibentuklah semacam panitia yang mengupayakan status tanah garapan empat lima. Pemerintah akhirnya menerbitkan surat kuning (UU Darurat No. 8) untuk memberikan kekuatan hukum atas status tanah tersebut kepada masyarakat.

Nasib surat kuning tersebut pupus di tengah jalan karena panitia menarik kembali dengan alasan surat itu akan diganti dengan "surat asli" (kohir). Pada kenyataannya masyarakat tidak pernah menerima "surat asli" itu dan surat kuning milik masyarakat tidak dikembalikan lagi. Walaupun begitu masyarakat tetap gigih mempertahankan lahan garapan mereka. Sampai akhirnya masyarakat mengajukan usulan ke PPN (tingkat Jawa Barat hingga Menteri), kemudian masyarakat dipanggil untuk datang dii kantor parlemen di Jakarta pada tahun 1951 untuk melakukan dengar pendapat dan menyelesaikan persoalan.

Pada kesempatan tersebut Mr. Soedjarwo (Menteri Agraria) meminta masyarakat menunjukkan surat kuning. Akan tetapi karena surat kuning sudah ditarik oleh panitia, masyarakat tidak dapat menunjukkannya. Bertolak dari kenyataan itu, Mr. Soedjarwo kemudian melimpahkan persoalan tersebut kepada pendiri PPN karena PPN-lah yang dianggap mengetahui duduk perkara. Akhirnya timbullah kesepakatan antara pihak PPN dengan masyarakat untuk melakukan 
perjanjian kerjasama. Wujud kerjasama itu berbentuk pembagian penguasaan lahan 7:2 (setiap 9 $\mathrm{m}^{2}$ lahan, $7 \mathrm{~m}^{2}$ bagian masyarakat dan $2 \mathrm{~m}^{2}$ bagian PPN untuk ditanami karet). Kesepakatan ini berjalan hingga dua tahun karena setelah dua tahun pohon karet membesar dan sebagai akibatnya pertanian masyarakat tersisih dan sebagian warga desa menjadi buruh di perkebunan karet PPN.

Memasuki tahun 1960, situasi pun berubah dengan dilaksanakannya land reform. Sebagian tanah yang ada dikembalikan kepada masyarakat sebagai penggarap. Tetapi situasi tersebut tidak lama, karena tanah yang digarap kembali diminta paksa oleh Negara. Tanah akan dipergunakan oleh PTP XI. Meskipun demikian ada beberapa areal yang tetap diperuntukkan bagi masyarakat, terutama di lereng-lereng bukit dan persawahan.

Memasuki akhir periode 1980-an dan 1990-an (1989), cerita masa lalu berulang. Tanahtanah yang masih dikuasai masyarakat, yaitu lahan garapan empat lima dibebaskan secara paksa demi kepentingan Negara membangun perkebunan teh. Untuk kepentingan itu masyarakat mendapat ganti rugi Rp 200/m². Pada faktanya sesudah pembebasan selesai dilaksanakan, tanah itu diserahkan kepada PT FAM, ABS, dan Panggung. Tanah yang dialihkan itu terdiri dari seluruh tanah yang tercantum dalam peta PTP XI ditambah sebagian tanah garapan masyarakat yang strategis untuk parwisata. Tanah itu sebagian telah bersetifikat HGU yang berakhir pada tahun 2011 dan 2025. Kurang lebih selama lima tahun tanah yang telah beralih kepada tiga perusahaan tersebut ditelantarkan dan sempat digarap kembali oleh masyarakat. Tanah-tanah itu kemudian dilebur di dalam penguasaan PT AP, atau dengan kata lain ketiga perusahaan tersebut melebur menjadi PT AP.

Selanjutnya PT AP melakukan ekspansi dengan jalan membebaskan tanah-tanah garapan masyarakat yang sudah memiliki tanda bukti GIRIK baik lahan darat, persawahan maupun permukiman penduduk dan tanah makam. Tanah makam dipindahkan ke luar desa yang letaknya jauh dari permukiman penduduk, dan luas lahan gantinya tidak sesuai dengan luas tanah makam sebelumnya. Sampai sekarang PT AP menguasai tanah seluas 1.697 ha yang mencakup 9 desa di 2 kecamatan di Kabupaten Bogor (Caringin dan Cijeruk) serta 2 kecamatan di Kabupaten Sukabumi (Cicurug dan Nagrak).

\section{Penetrasi Kapitalis dan Marginalisasi Petani}

Konsep dasar pengembangan agrowisata di Lido akan memadukan kegiatan pertanian modern dengan tempat peristirahatan, hunian dan olah raga. Sedianya akan dibangun beberapa fasilitas seperti taman rekreasi, public facility, Lido Resort, golf villas, honey hill, grand terrace, air 
strip, ATV, kebun durian, dan jati, serta perumahan mewah. Untuk merealisasikan tujuan tersebut dilakukanlah program-program sebagai manifestasi cara produksi yang berorientasi pada kegiatan komersial. Program-program ini apabila dikaitkan dengan objek agraria, yaitu tanah dan air, merupakan suatu upaya untuk merubah potensi agraria pertanian menjadi potensi wisata. Dalam pandangan petani, prinsip subsistensi atas potensi agraria pertanian termanifestasi ke dalam budidaya pertanian tanaman pangan, seperti padi, sayur-sayuran, dan buah-buahan. Maka program swasta merubah potensi agraria merupakan bentuk penetrasi ke dalam struktur komunitas desa pertanian. Penetrasi merupakan suatu bentuk intervensi dan gangguan struktural bagi sistem sosial petani.

Bentuk-bentuk penetrasi swasta di Lido ditengarai melalui tiga program PT AP, yaitu pembebasan tanah, realisasi program, dan pemungutan sewa tanah. Dalam rangka pembebasan tanah, pihak PT AP mendatangi petani untuk membebaskan lahan garapan empat lima. Akan tetapi kemudian mereka juga mengusik tanah garapan PTP XI, persawahan, dan perkampungan. Pembebasan tanah dilakukan dengan cara memanfaatkan tokoh-tokoh masyarakat, aparat desa, dan aparat militer. Mereka membujuk, menakut-nakuti, mengancam dan bertindak kekerasan sehingga mau tidak mau masyarakat menyerahkan lahan garapan mereka. Untuk menghindari kesan tidak baik di mata masyarakat dan juga demi kelancaran pembebasan, PT AP mengatur posisi tugas seorang tokoh desa yang tergabung dalam panitia. Mereka ini umumnya para makelar tanah yang menjalankan kerjanya di desa lain. Para makelar ini tugas utamanya mendatangi dan membujuk masyarakat agar bersedia menjual tanahnya. Apabila tidak bersedia maka disebar isu akan diambil paksa termasuk ditakut-takuti oleh oknum polisi militer.

Akibat cara-cara dan kejadian ini berlangsung cukup lama, akhirnya masyarakat menyerah. Proses pembebasan tanah berlangsung dalam tiga tahap. Tahap pertama tanah yang

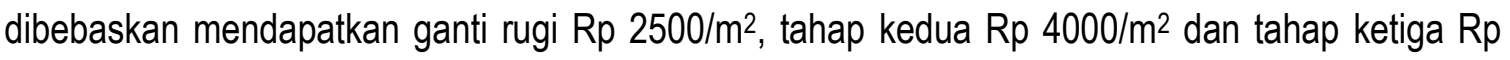
$5000 / \mathrm{m}^{2}$. Proses ganti rugi ini penuh dengan manipulasi, misalnya dilakukan di atas kuitansi kosong rangkap tiga, pengukurannya tidak otentik, dan banyak menggunakan nama-nama palsu.

Untuk merealisasikan program sesuai dengan master plan, PT AP menempuh jalan yang hampir sama dengan pembebasan tanah, yaitu membuat isu pengggusuran, menakut-nakuti, memaksa, hingga menggunakan tindakan kekerasan. Tindakan pemaksaan kepada petani sering dilakukan tatkala realisasi pembangunan fasilitas wisata masih jauh dari pelaksanaan seperti perintah mengosongkan lahan dan membongkar rumah serta bangunan lain. Apabila masyarakat menolak maka aparat satpam dan bahkan polisi menebangi tanaman yang ditanam petani dan 
membongkar paksa bangunan rumah warga. Dalam satu kasus, yaitu pembangunan tempat rekreasi danau Lido dan jalan masuk utama (entrance gate), dilakukan penimbunan untuk memotong aliran air ke dalam danau. Padahal di sekitarnya banyak lahan garapan warga desa yang juga melakukan aktivitas penangkapan ikan pada sungai-sungai kecil yang ditimbun itu. PT AP sengaja membuldoser lahan warga meskipun proses ganti rugi belum selesai karena ada sebagian warga yang enggan menerima uang ganti rugi karena dianggap terlalu rendah.

Penyebaran isu bahwa akan dilakukan pembangunan fasilitas wisata pada kenyataannya dilakukan jauh-jauh hari sebelum pembangunan itu benar-benar terealisasi. Jadi isu yang menggelisahkan warga sudah merebak di kampung-kampung tempat bermukimnya para penduduk desa. Pasalnya PT AP merekrut beberapa warga desa untuk bekerja menjadi satpam dan di divisi pengamanan lahan. Mereka menjadi kaki tangan perusahaan agar memudahkan realisasi pembangunan agrowisata. Petani menyebut mereka sebagai "mata-mata" perusahaan karena mereka selalu memberikan informasi dan masukan kepada PT AP tentang rencanarencana petani.

Sejak terjadinya krisis ekonomi tahun 1998/1999 dimana terjadi PHK besar-besaran dan kerawanan sosial ekonomi di Indonesia, dampak krisis juga melanda warga masyarakat Lido. Berbekal instruksi Presiden BJ Habibie pada waktu itu bahwa tanah-tanah terlantar dapat digarap oleh petani, petani Lido menggarap tanah-tanah yang telah dibebaskan PT AP yang belum dimanfaatkan. Atas aksi sepihak ini, PT AP membuat kebijakan mengenai pemungutan sewa tanah atas tanah-tanah yang digarap petani. Jumlah penggarap yang tercatat pihak PT AP sebanyak 514 orang dengan total garapan seluas $470.481 \mathrm{~m}^{2}$ (47 ha). Petani mayoritas menggarap lahan kurang dari 0,5 ha.

Pada mulanya sewa tanah langsung dipungut kepada petani tanpa melalui pihak desa. Adapun besarnya sewa tanah yang dibebankan kepada petani sebesar Rp 15/m²/ musim jagung (4 bulan) untuk katagori lahan darat dan $\mathrm{Rp} 22,5 / \mathrm{m}^{2} / 6$ bulan untuk sawah. Jadi petani penggarap mesti membayar uang sewa dua atau tiga kali dalam setahun, apapun yang ditanam petani. Namun sejak Februari 2002 terjadi kesepakatan antara pihak perusahaan dengan Kepala Desa dan BPD tentang pembagian hasil pemungutan sewa tanah dimana pembayaran sewa tanah dilakukan kepada PT AP atas bantuan aparat desa. Telah disepakati pembagian hasil itu sebesar $25 \%$ pihak desa dan $75 \%$ pihak perusahaan.

Perjanjian sewa tanah ini sangat ganjil. Pertama, PT AP tidak memperhatikan keragaman tanaman petani. Karena harga yang tidak menguntungkan, ternyata hanya sedikit petani yang 
menanam jagung dan sebagai gantinya petani menanam pisang (setahun) dan singkong (6 bulan). Kedua, perjanjian dibuat sepihak tanpa proses dialog bersama petani. Akibatnya dalam salah satu butir perjanjian itu tertera pernyataan bahwa petani akan menyetujui jika sewaktu-waktu tanah dipergunakan oleh PT AP, petani tidak akan menuntut ganti rugi. Ketiga, dalam pelaksanaannya, pemungutan sewa tanah oleh petugas sering melebihi ketentuan dan dilakukan sebelum waktunya, yaitu pada saat petani belum panen bahkan dalam keadaan gagal panen sekalipun. Termasuk juga petani yang tidak menandatangani perjanjian sewa tanah, tetap berkewajiban untuk membayar sewa tanah atas tanah yang digarapnya karena adanya manipulasi surat perjanjian dalam bentuk pemalsuan tanda tangan.

\section{Kerawanan Struktural, Jebakan Tengkulak, dan Krisis Subsistensi}

Akibat ketiga proses yang dijalankan pihak perusahaan petani mengalami marginalisasi baik secara teknis maupun strategis. Secara teknis, petani kehilangan kebebasan mengelola tanah, mengalami pengusiran, dan tekanan psikologis. Petani dilarang menanam tanaman tahunan dan bangunan di atas tanah, mendapatkan perintah mengosongkan lahan, serta rasa ketakutan yang mencekam akibat ancaman petugas PT AP dan aparat keamanan negara. Secara strategis, petani kehilangan tanah milik yang diperoleh melalui pewarisan para pendahulunya. Dengan kata lain penetrasi kapitalis swasta ke tengah-tengah komunitas desa telah menghilangkan penguasaan petani atas sumber-sumber strategis milik mereka dan sebagai gantinya petani hanya menjadi penggarap di atas tanah-tanah yang sudah mereka kuasai berpuluh-puluh tahun.

Kehilangan tanah merupakan kerawanan struktural akibat bekerjanya aktor-aktor di luar petani dan perusahaan dimana pihak perusahaan menggunakan aparat keamanan, aparat pemerintah, dan anggota DPRD sebagai pihak yang secara terang-terangan selalu mendukung dan melindungi kepentingannya. Dalam kaitannya dengan hubungan negara dan rakyat, lembagalembaga negara menjalankan kontrol politik atas warga desa dan petani. Legitimasi pihak berwenang merupakan pembenaran bagi perusahaan untuk berbuat apapun terhadap petani yang menghalangi kepentingannya. Terdapat hubungan kolaboratif-manipulatif di sini dimana negara di tingkat daerah berkepentingan untuk melaksanakan pembangunan demi mengejar pertumbuhan ekonomi sedangkan perusahaan berkepentingan mendapatkan keuntungan materi. Selama bentuk hubungan ini terjadi maka kepentingan petani akan dikorbankan, walaupun menyangkut hajat hidup orang banyak seperti kasus penggarapan lahan pertanian di Lido. 
Dalam kondisi demikian petani menghadapi ancaman krisis subsistensi. Kondisi menjadi semakin berat karena ketidaksanggupannya menghadapi fluktuasi harga pasar dan sebagai akibatnya petani terlibat dalam hubungan rente tengkulak yang sulit diputus. Sebagaimana telah diuraikan sebelumnya, sejak tahun 1998 petani mulai menggarap lahan-lahan yang telah dibebaskan untuk ditanami tanaman padi, pisang, singkong, ubi jalar, kacang buncis, cabe, dan jagung. Untuk memenuhi kebutuhan saprodi seperti bibit, pupuk, dan pestisida, petani meminjam uang kepada tengkulak dengan bunga cukup besar serta berkewajiban menjual kepada tengkulak yang bersangkutan.

Interaksi petani-tengkulak menyebabkan ketergantungan luar biasa. Misalnya, jika petani membutuhkan uang untuk kebutuhan non produksi, maka tengkulak akan memberikan pinjaman dengan bunga tertentu. Kebutuhan untuk membeli bahan makanan pokok seperti beras dan minyak misalnya, demikian juga kebutuhan yang tidak terduga seperti anggota keluarga sakit, petani boleh meminjam uang kepada tengkulak. Sebagai konsekuensinya tengkulak akan memotong harga jual hasil tanamannya dengan besarnya utang ditambah bunga pada waktu panen.

Sebagai akibatnya uang yang dipinjam itu bukannya menolong tetapi mencolong hasil pendapatan petani. Petani seolah-olah tidak memiliki kuasa apapun terhadap hasil tanamannya. Pisang misalnya, petani menjual pada waktu masih muda dengan harga sangat murah. Begitu pula dengan jagung, singkong, dan tanaman lain yang diproduksi dengan modal pinjaman tengkulak. Seringkali petani tidak mendapatkan apa-apa dari jerih payahnya merawat dan menunggu tanamannya, paling maksimal petani hanya menerima sisa uang setelah dipotong utang kepada tengkulak. Tidak jarang utang berikut bunganya melebihi nilai jual produknya.

Keberadaan tengkulak secara praktis menghalangi akses informasi terhadap harga pasar atas produk input dan output petanian. Perubahan harga pasar seringkali tidak mampu diantisipasi oleh petani pada tingkat pola tanam. Akibatnya petani tertipu oleh tengkulak dan juga oleh pemain pasar. Sebagai contoh, pada waktu harga cabe masih tinggi petani ramai-ramai menanam cabe. Pada waktu panen harga cabe merosot tajam hingga petani menderita kerugian besar. Dalam keadaan demikian tengkulak tetap menarik utang dan bunga yang disepakati akan dibayar saat panen.

Sebenarnya para tengkulak tidak selalu berbuat tidak jujur dengan menaikkan atau menurunkan harga sesuai harga pasar. Hanya saja para tengkulak mematikan persaingan dan cenderung bertransaksi secara tidak sehat. Untuk komoditas output, tengkulak cenderung 
menekan harga jauh di bawah harga pasar. Jika harga pasar mengalami kenaikan, ia turut menaikkan tetapi hanya sedikit. Sebaliknya input pertanian cenderung dispulai kepada petani dengan harga jauh di atas harga pasar. Apabila harga pasar mengalami penurunan, ia juga menurunkan tetapi hanya sedikit. Kesediaan tengkulak mengikuti harga pasar tidak berpengaruh signifikan bagi perbaikan ekonomi rumah tangga petani.

Sebenarnya Scott tidak pernah menyebutkan batas ambang subsistensi yang dapat ditolerir petani, sehingga di atas ambang itu telah terjadi krisis subsistensi (Scott 1983). Suatu kondisi yang memberatkan petani merupakan situasi yang didefinisikan petani sebagai bentuk bertahan karena tidak ada pilihan lain. Kegiatan bertani tanaman pangan yang penuh dengan ketidakpastian juga belum mencukupi kebutuhan subsiten keluarganya. Melakukan usaha tani sebenarnya sudah tidak masuk akal lagi apabila bukan disebabkan oleh adanya hubungan yang erat antara petani dan tanah. Tanah Lido memiliki akar sejarah yang panjang dalam pola penggarapan masyarakat desa. Atas landasan ini, walaupun penuh dengan resiko, usaha tani tetap dijalankan. Pola nafkah ganda merupakan konsekuensi logis untuk mempertahankan tingkat subsistensi rumah tangga. Beberapa variasi bentuk pencarian nafkah yang umum dijumpai di desa penelitian adaah berdagang kecil-kecilan, berdagang keliling, membuka usaha kerajinan anyamanyaman bambu dan dangdang. Disamping itu kiriman anggota keluarga yang bekerja di daerah perkotaan juga diandalkan untuk mengantisipasi kebutuhan yang besar seperti bulan puasa dan hari raya. Beberapa sektor yang dapat dimasuki oleh pemuda desa adalah buruh pabrik tekstil, restoran, dan buruh bangunan di Kota Sukabumi, Bogor, dan Jakarta. Jumlah anggota keluarga yang bekerja di luar desa itu pun sebetulnya tidak begitu banyak. Masih lebih banyak pemuda yang menganggur kecuali mereka yang menjadi tukang ojeg di sekitar desa.

Belum lagi untuk mencukupi kebutuhan pendidikan dan kesehatan. Banyaknya anak yang putus sekolah dan berhenti sampai dengan tingkat SMP tidak lain disebabkan oleh ketidaksanggupan masyarakat membiayai anaknya menuntut ilmu pada pendidikan formal. Kondisi kesehatan masyarakat cukup memprihatinkan terutama kesehatan ibu dan anak. Ketiadaan sarana transportasi dan kondisi jalan penghubung antar kampung yang buruk menyulitkan para ibu yang akan melahirkan dengan pertolongan medis. Sebagai gantinya proses kelahiran dibantu oleh paraji atau dukun setempat yang sangat minim pemahamannya mengenai kesehatan medis. Status gizi anak-anak pun demikian. Suatu survey dilakukan Lembaga Pengembangan dan Advokasi Masyarakat (LPAM) yang berkedudukan di Jakarta pada bulan Februari-April 2001 di Desa Wates Jaya dengan mengggunakan standar Depkes dan NCHS 
(WHO) terhadap 255 anak berusia 3-10 tahun. Hasilnya menunjukkan bahwa terdapat 9 anak berstatus gizi buruk, 164 anak dengan status gizi kurang, dan 82 anak berstatus gizi cukup. Kondisi gizi seperti itu tidak dapat dilepaskan dari kemiskinan yang dialami warga desa selama bertahun-tahun. Bahkan terhadap keseluruhan keadaan tersebut, marginalisasi merupakan jalan yang menghantarkan pada keadaan miskin, pendidikan rendah, dan kesehatan rendah.

\section{Perlawanan Petani Penggarap Lido}

Terbentuknya organisasi tani Lido merupakan proses yang panjang setelah bertahuntahun menggarap lahan dengan status yang tidak menentu. Organisasi tani ini kelak menjadi wadah untuk melakukan perlawanan menyikapi krisis subsistensi akibat kondisi yang tidak menguntungkan. Pada masa-masa awal perlawanan petani dilakukan secara tidak terorganisir. Bentuk-bentuk yang umum dilakukan pada masa itu adalah penolakan ganti rugi dan penandatanganan surat perjanjian, pematokan jalan, pencangkulan lapangan wisata pesawat terbang, penggarapan tanah, dan demonstrasi. Penolakan-penolakan terhadap penjualan tanah kepada para makelar misalnya, semata-mata petani enggan melepaskan lahan garapan. Petani yang menunda penjualan tanah akan memperoleh harga yang lebih tinggi, dilakukan secara spontan dan tanpa koordinasi. Dengan melakukan penundaan-penundaan, perilaku ini cukup menyulitkan para makelar sehingga untuk mempercepat proses jual beli pihak perusahaan menempuh cara-cara yang penuh dengan kekerasan. Pada saat akan dilakukan pembangunan entrance gate dan recreation park, para petani yang terkena dampak melakukan upaya penentangan mulai dari penolakan hingga pasang badan di lokasi-lokasi yang akan dibangun.

Munculnya kesadaran berorganisasi, terutama pada saat petani mengikuti program pemberdayaan masyarakat yang diselenggarakan oleh LPAM Jakarta. Bermula dari pertemuanpertemuan bulanan yang difasilitasi oleh LPAM, para petani mulai menyadari bahwa tidak adanya koordinasi yang terencana merupakan salah satu penyebab lemahnya posisi petani ketika harus berhadapan dengan pihak perusahaan. Selain diikuti oleh peserta program pemberdayaan, pertemuan juga dihadiri oleh petani non peserta, aparat desa dan BPD. Pada bulan Oktober 2001, petani membentuk Paguyuban Petani Penggarap Lido (P3L).

Atas inisiatif Ketua BPD, para petani menyepakati untuk melakukan unjuk rasa di depan kantor PT AP. Keberanian berunjukrasa muncul setelah mereka merumuskan permasalahanpermasalahan bersama. Untuk itu disusun agenda tuntutan mereka kepada pihak perusahaan, yaitu penghapusan sewa tanah dan pemberian kompensasi sosial atas beroperasinya wisata pesawat terbang. Akan tetapi unjuk rasa ini tidak ditanggapi serius oleh PT AP. Pihak manajemen 
tidak memberikan jawaban yang memuaskan sehingga unjuk rasa nyaris tidak membuahkan hasil yang nyata. Sebagai tanda keputusasaan, petani mematok ruas jalan yang menuju ke Lido Resort dan mencangkuli landasan pesawat terbang. Kemudian para tokoh petani, petani,, dan anggota BPD berkumpul di saung tempat mereka mengadakan pertemuan bulanan. Mereka melakukan evaluasi aksi yang baru saja dilakukan. Beberapa petani mengusulkan agar ada aksi lanjutan dengan mengerahkan massa yang lebih banyak.

Pertemuan rutin mereka lakukan hampir setiap mingggu untuk mematangkan tuntutan mendasar petani dari sekian banyak tuntutan yang berbeda-beda. Hasil curah pendapat mereka menyimpulkan tuntutan utamanya adalah pengembalian tanah. Tuntutan tersebut akan diajukan kepada DPRD Kabupaten Bogor. Dalam hal ini petani menginginkan pihak Desa Wates Jaya bersedia mewakilinya.

Tuntutan pengembalian tanah-tanah garapan petani itu salah satunya dipicu oleh kondisi PT AP yang berada dalam sita jaminan BI atas aset-aset Bank Pasific karena terkena likuidasi pada masa krisis moneter. Para petani ramai membicarakan kemungkinan PT AP beserta tanah yang dikuasainya akan disita oleh negara melalui BPPN. Para petani pun meyakini setelah disita oleh Negara, menurut undang-undang tanah bekas kekuasaan PT AP itu akan didistribusikan menjadi milik masyarakat.

Atas nama Desa Wates Jaya, Kepala Desa beserta para petani melakukan protes ke DPRD Kabupaten Bogor pada tanggal 9 Oktober 2001. Tujuannya semata-mata untuk mengadukan sengketa yang mereka hadapi dengan pihak PT AP. Pada kesempatan itu petani membacakan tuntutan pokok dan beberapa tuntutan lainnya, yaitu hentikan pemungutan sewa tanah dan pemberian tanah makam beserta biaya pengurusannya. Setelah mendengarkan dan mempelajari pengaduan petani, Komisi A DPRD Kabupaten Bogor yang menerima petani berjanji akan memanggil utusan petani untuk dipertemukan dengan pihak PT AP.

Beberapa hari pasca unjuk rasa, terjadi keganjilan di pihak petani, BPD, dan Kepala Desa. Ketua BPD yang memprakarsai unjuk rasa di depan kantor PT AP dinilai memanfaatkan petani untuk kepentingannya sendiri. Pada awal menjelang unjuk rasa, Ketua BPD terlihat aktif dan bersemangat membela petani. Akan tetapi nyatanya hal itu sengaja dilakukan untuk mencari sensasi dan simpati di hadapan manajemen PT AP. Sedangkan kepala desa merasa dimanfaatkan oleh tokoh petani. Pasalnya ketika mengajukan masalah ke DPRD petani langsung diwakili oleh kepala desa. la menyesalkan karena dalam perkembangannya, petani membentuk organisasi tani yang mewadahi seluruh petani penggarap di bawah paying P3L. Menurutnya 
perjuangan petani sebaiknya dilakukan dengan prosedur formal dalam kesatuan desa dengan nama Pejuang Petani Penggarap yang mewadahi keseluruhan petani desa. Sebaliknya dalam pandangan petani wadah itu akan efektif jika hanya menampung petani yang menggarap di tanah sengketa. Disamping itu petani juga menuding kepala desa telah terkooptasi oleh kepentingan PT AP yaitu disuap agar tidak mengusik masalah kepemilikan tanah.

Pada tanggal 20 November 2001, Komisi A DPRD Kabupaten Bogor mempertemukan petani Desa Wates Jaya dengan PT AP dan Pemkab Bogor di ruang rapat utama gedung DPRD Kabupaten Bogor. Pada kesempatan itu petani yang tergabung ke dalam P3L didampingi oleh kuasa hukumnya dari LBH Jakarta. P3L telah mempersiapkan beberapa argumentasi berkaitan dengan tuntutan pengembalian tanah. P3L akan membacakan sejarah tanah sampai perlakuanperlakuan yang mereka alami pada saat pembebasan tanah, penipuan pihak perusahaan, sampai dampak sosial ekonomi bagi masyarakat desa.

Namun setelah acara dibuka, pimpinan rapat meminta tiga pengacara dan pendamping P3L untuk meninggalkan ruangan. Alasan yang dikemukakan bahwa forum DPRD adalah forum politik sedangkan pengacara baru dipandang perlu hadir nanti pada saat di pengadilan. Atas penolakan itu, pengacara P3L menjelaskan bahwa mereka adalah kuasa hukum yang mempunyai hak bertindak atas nama klien. Akan tetapi pihak komisi $A$ tetap bersikeras menolak kehadiran pengacara petani. Komisi $A$ menjelaskan bahwa ia tidak mengundang pengacara dan di dalam tata tertib DPRD Kabupaten Bogor tidak memperkenankan pihak-pihak yang tidak ada kaitannya dengan rapat, hadir dalam ruangan rapat. Perdebatan kedua belah pihak tidak berujung pada penyelesaian dan akhirnya pengacara petani dan wakil-wakil petani melakukan walk out dari ruang rapat.

Keesokan harinya tanggal 21 November 2001, LBH Jakarta menggelar siaran pers di Jakarta perihal kejadian tersebut sekaligus meluruskan berita yang dimuat Koran Tempo edisi 21 November 2001. Dalam pemberitaan tersebut terdapat kekeliruan pelaporan, yaitu diberitakan setelah petani melakukan walk out terjadi pertemuan kembali dengan pihak DPRD, PT AP, dan Pemkab Bogor. Pemberitaan tersebut memberikan kesan bahwa petani menerima hasil kesepakatan yang mereka buat yaitu bahwa kedudukan PT AP sudah sah secara hukum.

Pasca insiden di gedung DPRD Kabupaten Bogor, petani menyikapi dengan strategi cooling down karena terjadi keretakan dalam tubuh organisasi tani. Keretakan itu mulai dari timbulnya rasa curiga satu sama lain karena isu pihak PT AP dan aparat pemerintah melalui kepala desa, direkrutnya para aktivis sebagai karyawan PT AP sekaligus menjalankan peran 
pembocor informasi. Sebagian petani bahkan merasa putus asa dengan harapan berhasilnya tuntutan mereka. Untuk itu strategi cooling down dianggap pilihan tepat sambil menunggu eksekusi atas penetapan sita jaminan BI terhadap aset-aset PT AP. Akan tetapi proses mengembalikan kepercayaan terus berjalan meskipun pertemuan-pertemuan tidak seintensif dulu.

\section{KESIMPULAN}

Sebagai penutup, pembahasan dialektika penetrasi dan resistensi ini berhasil merumuskan suatu dinamika sengketa agraria di tanah Lido. Sengketa dilustrasikan sebagai hubungan dialektis pelaku konflik dengan dukungan struktural masing-masing pihak menjadi hubungan yang sulit untuk diprediksi ujungnya. Secara skematis dinamika ini digambarkan pada Gambar 1.

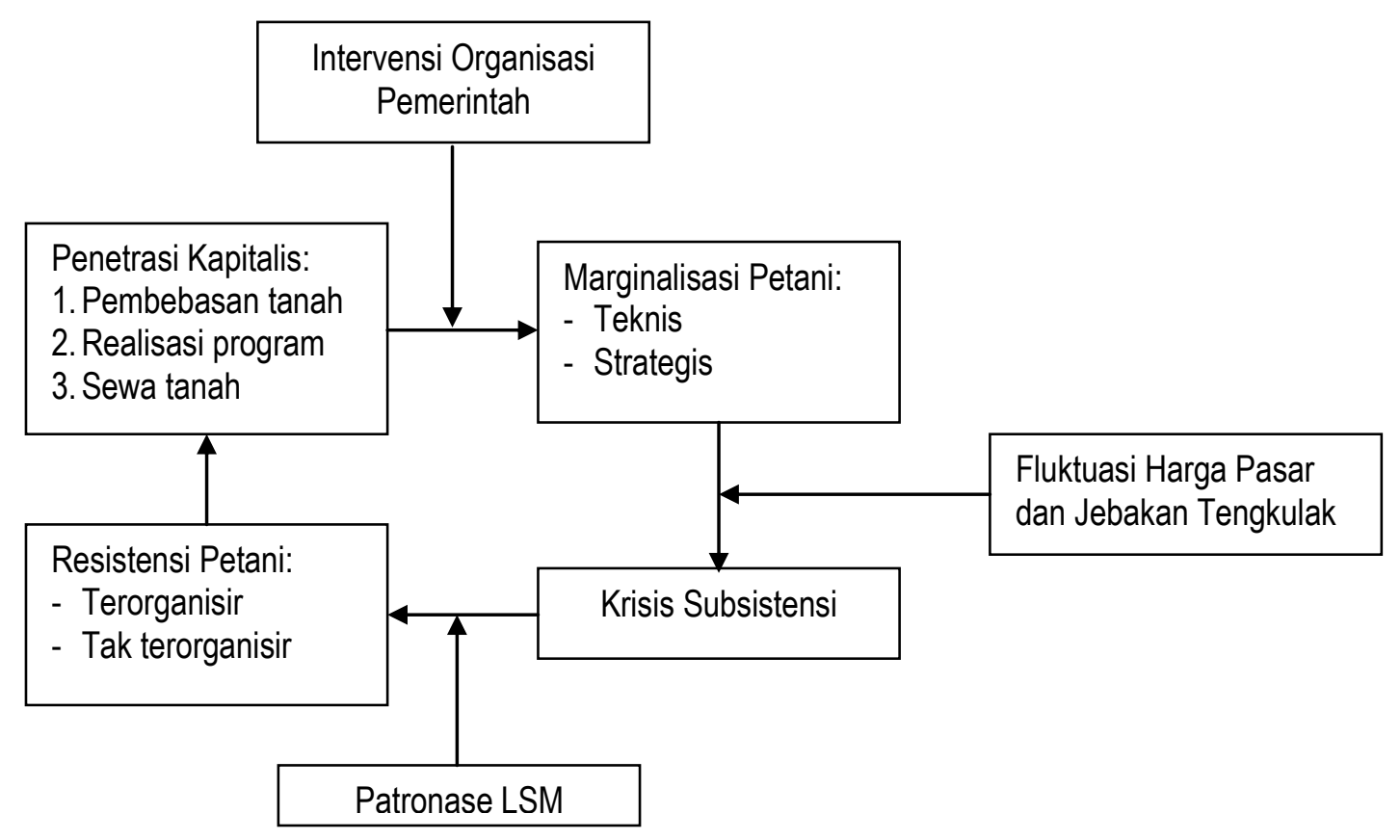




\section{DAFTAR PUSTAKA}

Bachriadi D dan Lucas A. 2001. Merampas Tanah Rakyat: Kasus Tapos dan Cimacan. Jakarta, Kepustakaan Populer Gramedia.

Denzin, NK. Dan Yvonna S. Lincoln (eds). 2000. Handbook of Qualitative Research. Edisi ke-2. Thousand Oaks-London-New Delhi, Sage Publications, Inc.

Hafid JOS. 2001. Perlawanan Petani: Kasus Tanah Jenggawah. Jakarta, LATIN, LSSP.

Miles MB dan Huberman AM. 1992. Analisis Data Kualitatif: Buku Sumber Tentang MetodeMetode Baru. Terj. Jakarta, UI Press.

Moleong L. 2001. Metodologi Penelitian Kualitatif. Cet. Ke-14. Bandung, Penerbit PT Remaja Rosdakarya.

Pelzer K. 1991. Sengketa Agraria: Penguasa Kebun Melawan Petani. Terj. Jakarta, Penerbit Sinar Harapan.

[Radar Bogor], 16 November 2000. Dalmas Amankan Pembuldoseran Lahan Bukit Sentul. Beres? 18 Oktober 2000. Pembuldoseran Bok Sodong Terus Berlangsung, Ganti Rugi 19 Oktober 2000. HGB Bukit Sentul Bisa Dicabut. 28 Oktober 2000. Masalah Blok Sodong Beres, Kades Terima Duit Rp 300 Juta?

30 Oktober 2000. Petani Malasari Minta HGU No. 2 Nirmala Agung Tidak Diperpanjang. , 10 November 2000. Warga Cikarang, Inginkan 19 Hektar Tanah Eks PTPN VIII. , 13 November 2000. Penggarap Lahan Blok Sodong Somasi PT Bukit Sentul. , 23 April 2001. Pembangunan di Lahan Garapan Berlanjut. 26 April 2001. Penggarap Blok Sodong Kecewa.

[Koran Tempo], 21 November 2001. Warga Cijeruk Permasalahkan Lahan Lido.

Scott JC. 1983. Moral Ekonomi Petani: Pergolakan dan Subsistensi di Asia Tenggara. Cet. Ke-2. Jakarta, LP3ES. 1993. Perlawanan Kaum Tani. Jakarta, Yayasan Obor Indonesia. 2000. Senjatanya Oran-Orang yang Kalah: Bentuk-Bentuk Perlawanan Sehari-Hari Kaum Tani. Jakarta, Yayasan Obor Indonesia.

Sitorus MTF. 1998. Penelitian Kualitatif: Suatu Perkenalan. Bogor, DOKIS.

Stanley. 1994. Seputar Kedung Ombo. Tanpa Tempat Penerbit, ELSAM, INFID. 